\title{
Educating for Sustainability: The Crucial Role of the Tertiary Sector
}

\author{
Wendy Fehlner ${ }^{1}$ \\ ${ }^{1}$ Baden-Württemberg Cooperative State University, Hangstrasse 46-50, 79539 Lörrach, Germany \\ Correspondence: Wendy Fehlner, Baden-Württemberg Cooperative State University, Hangstrasse 46-50, 79539 \\ Lörrach, Germany. Tel: 49-7621-2071-178. E-mail: fehlner@dhbw-loerrach.de
}

Received: January 30, 2019

doi:10.5539/jsd.v12n2p18
Accepted: February 15, 2019 Online Published: March 30, 2019

URL: https://doi.org/10.5539/jsd.v12n2p18

\begin{abstract}
The Sustainable Development Goals of the United Nations represent a universal response to current global challenges that include climate change, poverty, political instability and the massive displacement of people worldwide. The central role of education in achieving sustainable development has been internationally acknowledged and successfully promoted: Global enrolment rates are now 90 percent for primary education and over 70 percent for secondary education. Building on these achievements, this paper focuses the role of tertiary education in contributing to sustainable development. This study reviewed recent theoretical and empirical research relating to the field. Conclusions from theoretical studies confirm that building on human capital is crucial for achieving the sustainable development goals. The majority of empirical studies also confirm a positive correlation between tertiary education and sustainable development. This study highlighted, however, that the full benefits of tertiary education to society may have been underestimated and that there are significant research gaps in the field. Furthermore, current challenges including funding, equity and market relevancy in tertiary education need to be addressed. Given the pressing global issues and the mounting evidence of positive impacts, this paper calls for more research and attention to be devoted to tertiary education in the sustainable development debate.
\end{abstract}

Keywords: sustainable development, economic growth, tertiary education, economic impacts, third mission

\section{Introduction}

We are currently facing global issues of an unprecedented scale. Climate change has resulted in potentially irreversible consequences for our planet. Population growth has burgeoned to over 7 billion today accompanied by increasing poverty levels. Political conflicts have threatened peace and democracy in many countries and have led to a massive increase of refugees around the world. As a consequence of these global trends, we presently have the highest levels of people displacement on record (UN, 2018).

The global community has long since recognized the necessity for a unified effort to address these challenges. This is reflected in the United Nations Millennium Development Goals and the more recent 2030 Agenda for Sustainable Development (UN, 2015). The overriding objective of these initiatives is to form collaborative partnerships among governments, public society and the private sector to end poverty, protect the planet and to ensure prosperity for all (UN, 2015). The Sustainable Development Goals (SDGs) address a broad range of issues including health, climate change, energy consumption, economic growth, employment, and institutional stability - all of which are discussed in this paper in connection with tertiary education.

The SDGs have successfully drawn attention to the central role of education for achieving the desired outcomes. There has been an enormous response from the international development community and much achievement: with the exception of Sub-Saharan Africa and South Asia, primary and secondary school enrolment worldwide has reached over 90 and 70 percent respectively (UN, 2014). According to a recent OECD report, ensuring that by 2030 all students gain a solid foundation of knowledge in key disciplines would have a substantial impact on sustainable development (OECD, 2015). Focusing on economic growth, other studies argue that improvements in primary and secondary education lead to GDP increases and have the potential to substantially increase societal living standards. In particular, the development of cognitive skills through mathematics and science curricula is viewed as crucial for long-term human capital development and prosperity (Hanushek and Woessmann, 2015).

The emphasis on basic education in the SDGs has meant that tertiary education (TE) has not been in the focus of 
international development work for the past two decades. It must be acknowledged, however, that any discussion of TE reforms must rest on the assumption that adequate primary and secondary schooling has been acquired. As authors Hanushek and Woessman (2015) point out, early skills attainment form the foundation on which TE can effectively build and without which long-term economic improvements cannot be achieved.

Yet, increasingly the significance of TE for building human capital and contributing to long run growth and prosperity is gaining more attention (Kruss et al., 2015). Tertiary education is seen as particularly important for driving economic growth in the emergence of globalized knowledge societies where advanced skills in the area of innovation and technology are crucial. Although measuring the full contribution of TE to growth has proven difficult, evidence suggests that TE graduates are more productive and better prepared for meeting the challenges of modern societies. A recent in-depth World Bank report focusing on the role of TE and growth found that for developing countries in particular, TE had the potential to transform economies, build stable societies and end extreme poverty (World Bank Group, 2017a). Furthermore, the positive impacts of TE extend beyond the economic sphere to areas relating to social and environmental concerns. TE has been associated with triggering beneficial changes in values, attitudes and behaviour on individual, community and societal levels (UNESCO, 2016).

The focus of the SDGs on basic education has diverted academic attention for a considerable time from TE resulting in a lack of research exploring the relationship between TE and sustainable development. However, it is only recently that the discourse on the benefits of TE has begun to gain ground (Oketch, McCowan and Schendel, 2014). Given the pressing global challenges and the mounting evidence of an altogether positive correlation between TE and sustainable development, the objectives of this paper are (1) to review the current literature on the relationship between TE and sustainable development, (2) to expose possible research gaps in this field, and (3) to draw attention to TE in the sustainability discourse.

\section{The Role of Education for Sustainable Development}

\subsection{Definitions and Theoretical Context}

Before examining recent literature pertaining to the fields of TE and sustainable development, it is necessary to clarify the terms and the various theoretical concepts referred to in this paper.

The broader term 'tertiary education' (TE) is used here to refer to all forms of post-secondary education that include, but are not limited to, universities, polytechnics, technical colleges, distance learning centres and business schools (UNESCO, 2011; World Bank Group, 2017b). The term 'higher education' is adopted when referring specifically to degree granting universities and colleges.

The term 'Sustainable Development' can be traced back to The Brundtland Report which defined the concept as one that 'meets the needs of the present without compromising the ability of future generations to meet their own needs' (World commission on Environment and Development, 1987, p. 16). The current discourse on sustainable development encompasses a broader spectrum of economic, environmental, political, social and technological issues involving complex interdependent systems that call for holistic, comprehensive and multidisciplinary approaches (Šlaus and Jacobs, 2011; UNESCO, 2016). The following discussion relies on this broader definition of sustainable development.

Related to the issue of sustainable development is the academic debate on whether the terms 'economic growth' and 'economic development' can be used synonymously. Several authors argue that whereas 'economic growth' can be defined as an increase in material output or GDP per capita, 'economic development' includes both economic and non-economic elements such as social and environmental aspects. This broader definition emphasizes achieving societal goals such as income equality, poverty reduction, improvements in health care, as well as broad access to education (Van den Berg, 2017). More recently, terms such as 'Green Growth' or 'Sustainable Growth' have been adopted and similarly reflect the idea that the challenge is to manage economic growth and development while ensuring that the natural resources are not depleted for future generations (OECD, 2017; World Bank Group, 2018; Oketch, McCowan and Schendel, 2014).

Other authors contend that economic growth and economic development can be considered as interrelated concepts because increases in growth contribute to development and development in turn fosters further growth (Oketch, McCowan and Schendel, 2014). A recent report from the Organization for Economic Co-operation and Development (OECD) argued that success in achieving the Millennium Development Goals will ultimately depend on economic growth which is positively correlated to levels of human capital in a society (OECD, 2015). The term 'human capital' has evolved from Adam Smith's capital stock definition of 'human ability' to a broader concept that is adopted in this paper and which includes the knowledge, skills, intellect, as well as human 
capacity for invention and innovation (Šlaus and Jacobs, 2011).

\section{Theoretical Approaches to Economic Growth and Development}

Although economists are generally in agreement with the proposition that fostering education positively impacts on economic growth and development, there are contesting conceptual explanations with regard to the factors and dynamics of this process. Authors Hanushek and Woessmann (2015) recognized three broad approaches to economic growth: augmented neoclassical growth theories, endogenous growth theories, and technological diffusion theories. These approaches provide the theoretical context for understanding the debates on economic growth and the rationale for education policy decisions.

The so-called 'augmented neoclassical growth theories', developed by Mankiw, Romer and Weil (1992) extended the basic growth model of Solow (1956) to incorporate human capital in the economic analysis. According to neoclassical theory, education increases human capital, which in turn boosts labour productivity and leads to a steady-state level of economic growth. Central to this neo-liberal school of thought is 'human capital theory', which originated from the work of Mincer (1974), but is predominately associated with the two Nobel prize-winners Theodore Schultz and Gary Becker. Their work, which emphasized the economic growth potential from investing in education, has been influential in framing national policies since the 1980s up until to the present day. Critics of this theory countered that human capital theory, with its focus on profit maximization, failed to adequately address ecological issues (Gillies, 2014) or to explain long-term growth dynamics (Kruss et al., 2015; Hanushek, 2016).

More recent endogenous growth theories address the issue of long-term growth by shifting the focus to growth rates of income (or GDP per capita) in an economy. In the neo-classical model, increases in human capital will raise levels of income, but will not change the long-term growth rate (Hanushek, 2016). Arrow's (1960) endogenous model stresses how work experience and "learning by doing" enhances labor performance over time resulting in improved technical processes and, ultimately, increased productivity (p. 155). Building on the work of Joseph Schumpeter, other proponents of endogenous growth theory (Lucas, 1988; Romer, 1990) emphasize how initial improvements in education levels within an economy will trigger innovation and technological progress and generate exponential and continuous long-run growth (OECD, 2015). Authors Aghion and Howitt (1992, p. 323) emphasize the role of research as a significant driver of economic growth through Schumpeter's process of "creative destruction" in which the promise of profits motivate a continual search for more effective innovations. Particularly in the context of increasing globalization and the transition to 'knowledge economies', endogenous growth theory has made an important contribution to explaining how human capital development impacts on long-term growth rates (Oketch, McCowan and Schendel, 2014; Barro and Sala-i-Martin, 2003).

Similar to neo-classical and endogenous growth models, human capital is also at the core of the technological diffusion theories. Economic growth, according to these theories, depends on how efficiently and effectively new technologies can be adopted by organizations. Based on the work of Nelson and Phelps (1966), these theories see investments in education as a key determinant in accelerating the spread of innovations and the implementation of technologies (Hanushek and Woessmann, 2015; Barro and Sala-i-Martin, 2003).

This very brief overview of economic growth theory highlights the differing explanations of how human capital contributes to economic growth and development. The emphasis is on increased labour productivity in neoclassical theory, fostering innovation and technology in endogenous theory, and facilitating the spread of these in technological diffusion theories. The central point here is that despite the contesting theoretical explanations of what constitutes economic growth, there is a general consensus among economists that improving education levels and thus building human capital is central to sustainable development (Hanushek and Woessmann, 2015).

\subsection{Economic, Environmental and Social Contributions of Tertiary Education}

The dynamics of how TE impacts on societies is often discussed within a framework of the three main pillars or functions of TE institutions, i.e., teaching, research and the 'third mission' as demonstrated in Figure 1: Tertiary Education's Diversified Roles (Marmolejo, 2016). However, in practice these roles cannot be viewed independently as they all contribute to productivity and sustainable development in complex symbiotic and reciprocal ways.

The first mission or teaching function of TE institutions is to develop human capital by advancing the knowledge, skills, and competencies of graduates seen as prerequisites for working in increasingly digitalized and innovative knowledge societies (Marmolejo, 2016). The research function of TE likewise contributes to sustainable growth by increasing research outputs and innovation and facilitating the implementation and spread of new 
technologies. The third mission function refers to the direct engagement of TE institutions with local communities and society in general and describes the social, environmental and cultural impacts of TE. This function contributes to sustainable development by positively impacting on aspects such as demographic trends, health, ecological awareness and civic responsibility (Oketch, McCowan and Schendel, 2014).

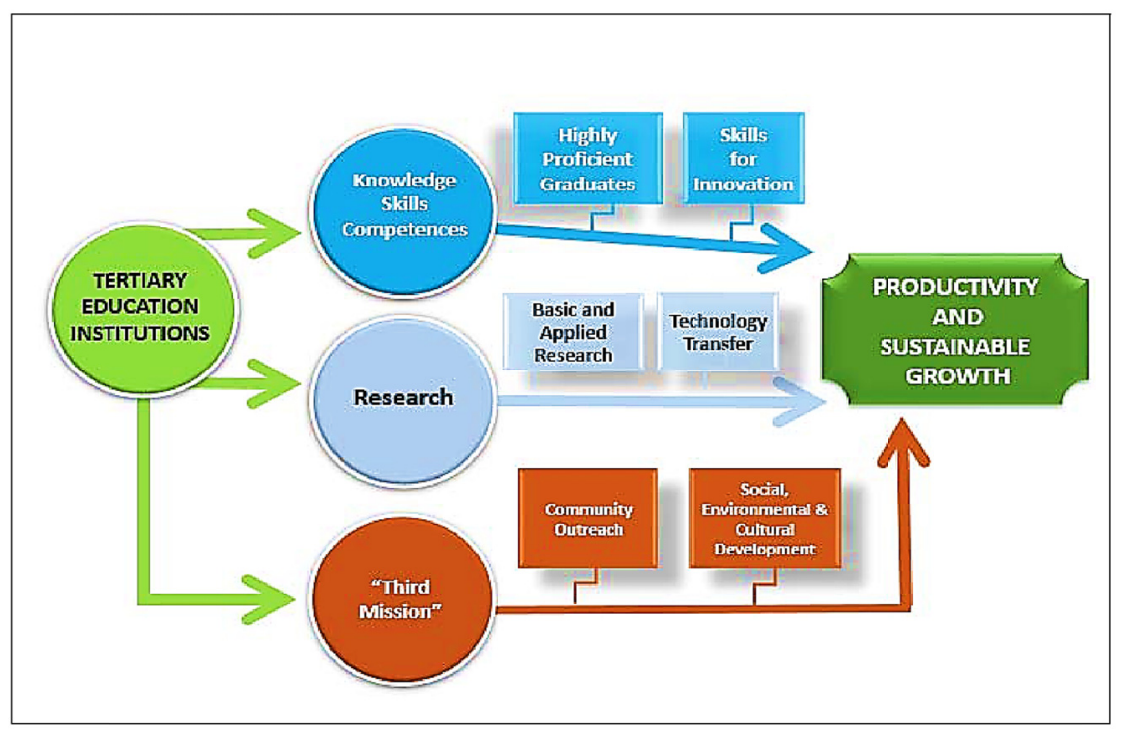

Figure 1. Tertiary educations' diversified roles (Marmolejo 2016, 14)

Much of the research on how TE affects development has centred on discussions associated with per capita incomes, GDP, productivity and innovation. In a systematic review of literature pertaining to TE and development, the authors found that most studies named higher earnings, increased productivity, improved capabilities and technological transfer as the key contributors to development (Oketch, McCowan and Schendel, 2014).

Various empirical studies, however, have highlighted the complexity of identifying and quantifying the factors contributing to growth which has resulted in contesting conclusions and policy recommendations (Hanushek and Woessmann, 2015; Oketch, McCowan and Schendel, 2014; OECD, 2015).

\section{Impacts of Teaching and Research on Sustainable Development}

Drawing on Human Capital Theory, investments in education increase labour productivity and result in higher earnings for individuals as well as economic growth for societies. The analysis of earnings is the most frequent studied criterion in connection with education and development (Oketch, McCowan and Schendel, 2014). A recent extensive empirical study based on World Bank World Development data from 139 economies between 1970 to 2013, showed that private returns to TE investment measured by net costs and benefits yields much higher returns than to secondary education, and interestingly, even higher returns to females in comparison to males: see Figure 2: Returns to Schooling (Montenegro and Patrinos 2014, p. 8). However, calculating the full social contribution of TE to economic development has proven a much more difficult task (Economist, 2015). 


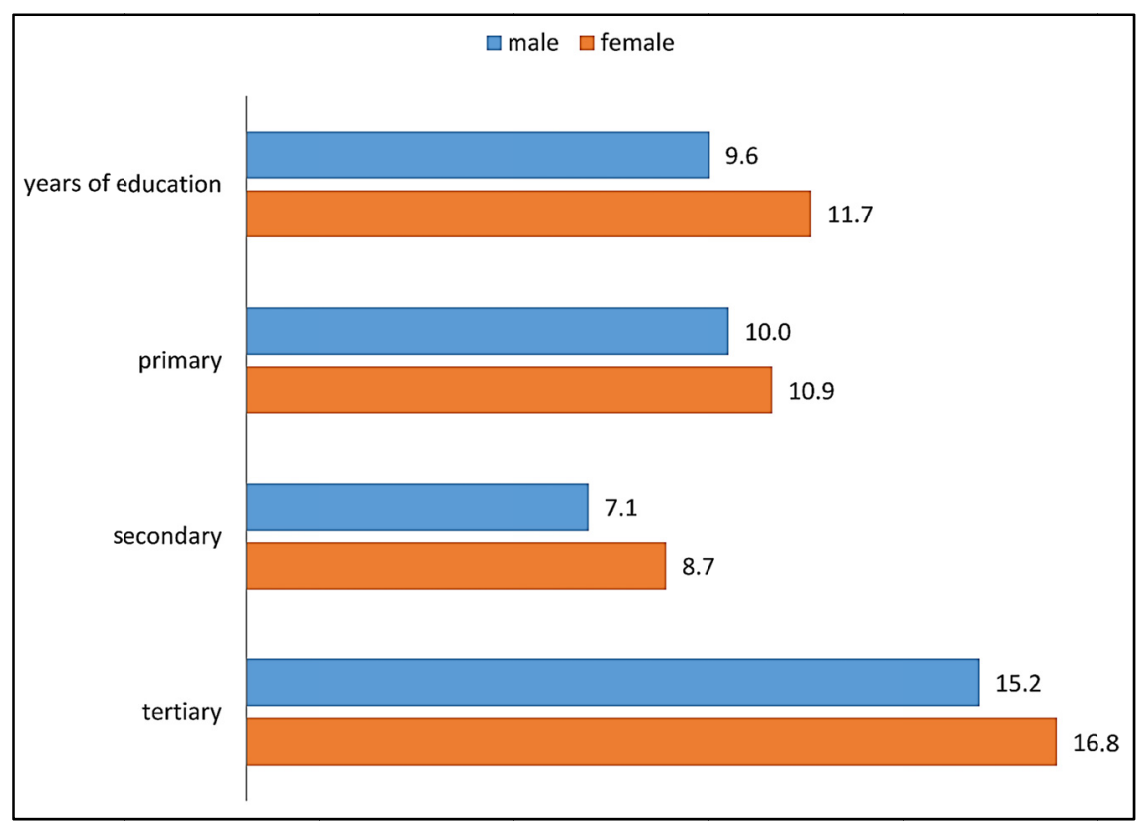

Figure 2. Returns to schooling (Montenegro and Patrinos 2014, 8)

Several World Bank studies in the late 1980s and 1990s argued that for low-income countries, the social returns to TE investment were substantially lower than for private returns. Furthermore, the social returns on investments in primary education doubled that for TE, which led to policy recommendations reflected in the Millennium Goals with the focus on universal basic skills (Haddad et al., 1990 cited in Oketch, McCowan and Schendel, 2014; Salmi and Basset, 2014). Studies by Hanushek and Woessmann (2015) adopted a similar view: These authors argued that with accurate measurement (i.e., the quality of education), the impact of basic education on long-term growth had been vastly underestimated. These authors conceded that TE yields private rewards but had little impact on long-term growth rates and therefore argued for investing in basic schooling first (Hanushek, 2016).

In the 1990s, proponents of endogenous theory broadened the focus from increased productivity through earnings to include a discussion of the impact of enhanced graduate capabilities on productivity. Recent empirical research in line with this theory takes a more positive view on the impacts of TE on economic growth and development. Accordingly, TE educated workers demonstrate an increased capacity to innovate and adapt technologies - considered crucial for knowledge societies - thus generating progressively higher productivity levels (Oketch, McCowan and Schendel, 2014, World Bank Group, 2017a; Montenegro and Patrinos, 2014).

Similarly grounded in endogenous theory is the discussion on how the research function of TE institutions impacts on sustainable development through positive externalities. In addition to the generation of research outputs, TE institutions play a central role in the creation of new knowledge which facilitates the replication, adaption and efficient implementation of new technologies resulting in higher productivity (Oketch, McCowan and Schendel, 2014). This is confirmed in a broad survey of the impact of TE on growth involving 108 countries between 1975 and 2010, which indicated that a one year increase in TE on average in Sub-Saharan Africa would increase the long-term GDP level by 16 percent and, in addition, increase growth by 0.06 percent per year through technological progress (Bloom et al., 2014). Further studies in this area highlight how the increased innovation of TE institutions spur greater national and global competitiveness in emerging knowledge economies (World Bank Group, 2017a).

Whereas some authors see universities as the best institutions for preparing societies for knowledge economies (Cloeate et al., 2013 cited in Nyerere et al., 2016), others are embracing the trend of increased research activity by non-university forms of TE such as colleges and business schools (Marmolejo, 2016). Not typically associated with research, these institutions are meeting a demand for applied research that is in alignment with market imperatives and supported by mutually beneficial partnerships with industry (Marmolejo, 2016). 
In summarizing their findings from an extensive literature review assessing TE and development, the authors found that although there is much research on individual productivity, there are significantly fewer empirical studies investigating the impacts of research and technology, particularly in low-income countries. Additionally, there are mounting calls for research that captures all the benefits of TE - private and social - as studies indicate that the benefits of TE could be far more positive than previously thought (Oketch, McCowan and Schendel, 2014).

\section{Third Mission Impacts on Sustainable Development}

In addition to the more frequently discussed teaching and research TE roles, the 'third-mission' role refers to interaction of TE institutions with communities, industry and society in general. Third mission activities are positively associated with sustainable development through a whole range of aspects relating to social progress and societal stability. These are often discussed in terms of non-market private benefits including improved health, reduced family size, and inclusion, as well as non-market public benefits such as ecological awareness, civic responsibility and improved institutions. Although evidence indicates that the third function of TE has substantial positive impacts, the full potential and contribution of this role has yet to be adequately analyzed and captured (Oketch, McCowan and Schendel, 2014; Marmolejo, 2016).

\section{Non-market private benefits}

With regard to non-market private benefits, several empirical studies from diverse regions such as Africa, Asia and the Middle East consistently confirmed positive correlations between TE and improved health outcomes. These outcomes covered a broad range of benefits including improved nutritional habits and hygiene, and responsible behaviour with regard to communicable diseases. A related impact was the improvement of health care services after graduates with enhanced capabilities enter the professional sphere generating further health improvements for the general public (Oketch, McCowan and Schendel, 2014).

Advanced education was also found to have a positive impact on demographic trends and population growth. Higher levels of education raised socio-economic aspirations leading to reduced fertility rates and improved family planning. Female education, in particular, led to improved family health and a reduced rate of child mortality (Šlaus and Jacobs, 2011). Studies show that university education had additional benefits for women in the form of later marriages, access to higher paid and more influential work as well as more decision-making power within the family and society (Oketch, McCowan and Schendel, 2014).

Furthermore, TE also had a positive impact on the inclusion of persons with disabilities. Although studies highlighted that access to universities remained difficult - particularly in Africa - the presence of students with disabilities was perceived to affect changes in attitudes toward these individuals in a positive way (Oketch, McCowan and Schendel, 2014).

\section{Non-market public benefits}

In addition to non-market private benefits, TE also had a substantial impact on non-market public benefits. TE has been influential in raising awareness of environmental issues and mobilizing the public to take action. In an extensive study of 33 countries over two decades, authors' Franzen and Vogl (2013) identified educational attainment as the most effective factor in triggering environmental concern. And the higher the level of education, the higher the propensity of citizens to get politically involved: The 2010 International Social Survey Programme involving 32 countries found that 46 percent of TE graduates had taken part in environmental action compared to 26 percent with secondary level and only 12 percent with primary level education (ISSP Research Group, 2012). In addition, TE is seen as a key determinant in the creation and implementation of innovative solutions for ecological challenges and limited resources (Nyerere et al., 2016).

The dissemination and exchange of knowledge are seen as additional non-market public benefits pertaining to TE in its third mission role. This can involve knowledge transfer to governments and industry in the form of research outputs in technology and innovation, and community outreach in the form of informative lectures, short courses, or other beneficial services. This sharing of knowledge can contribute to improvements in productivity, public support, as well as industry sponsorship and government funding (Oketch, McCowan and Schendel, 2014).

Further non-market public benefits of TE involve issues relating to social and civic responsibility. In the course of their lives, TE graduates act as opinion leaders and spread ideas of democracy and sustainability to general society. The magnitude of this student impact can be seen in the counter-culture hippie movement of the 1960s which evoked dramatic changes in values and attitudes relating to materialism, sexuality, racial tolerance, war, and environment across the globe (Šlaus and Jacobs, 2011). Studies also show that TE graduates are more likely 
to be informed, engage in critical debates, and be active in voluntary organizations and protest groups. They are also more inclined to hold positive views on democracy and be less tolerant of public office abuse. Societies can benefit from graduates who later take on political positions and foster good governance practices (Oketch, McCowan and Schendel, 2014; Marmolejo, 2016).

These non-market social benefits are closely associated with evidence that TE fosters social and political reforms leading to improved, efficient institutions and more stable governments. Empirical evidence from several less developed countries (LDCs) highlighted how TE was positively associated with increased democratic attitudes in Pakistan, political stability across Africa, and decreased tolerance for corruption in countries such as Kathmandu and Nepal (Oketch, McCowan and Schendel, 2014).

The previous discussion illustrates how TE through its roles of teaching, research and third mission can contribute to sustainable development. The competencies and skills attained by TE graduates not only help them find gainful employment and promote economic growth, but also enable them to contribute to the building of prosperous, just and stable societies (Marmolejo, 2016). The research role demonstrates how TE fosters the development and transfer of innovation as well as new technologies and drives competition leading to continuous growth and sustainable development. Moving beyond the formal traditional teaching and research roles, universities can be proactive by engaging with community, industry and government to find solutions to the task of creating sustainable societies (Nyerere et al., 2016). This discussion also demonstrates how the three TE roles of teaching, research and third mission are closely interrelated, each role supportive and complementary, and all contributing to the goal of achieving sustainable development (Oketch, McCowan and Schendel, 2014).

\subsection{Challenges for Tertiary Education}

A discussion of the impacts of TE on sustainable development would not be complete without a consideration of the current challenges facing TE institutions. Beforehand however, it is necessary to make explicit the assumptions on which any discussion of TE impacts is based. For TE to be of benefit to individuals and society, it is necessary that there is political and academic freedom to express critical ideas, that there is support for entrepreneurship as well as autonomy in the choice of research areas. Additionally, it is assumed that countries take measures to avoid brain drain by providing rewarding employment opportunities and, last but not least, that a solid foundation of basic skills is in place for TE to build on (Oketch, McCowan and Schendel, 2014). Even when these prerequisites are met, TE institutions face further challenges in areas such as equity, employability and funding (World Bank Group, 2017a).

There has been a phenomenal growth of TE enrolment worldwide from approximately 89 million students in 1998 to over 200 million today. Various reasons for this increase exist. One is the worldwide improvement in basic skill levels driven by the United Nations Millennium Goal initiatives. Another reason is a demographic trend: It is estimated that the world population of youth (aged between 10-24 years) will increase from 1.8 billion in 2010 to 4.9 billion by 2030. Regions such as Sub-Saharan Africa, MENA, and Latin America are particularly affected by this development. Not surprisingly, given the potentially high returns to TE, there is no lack of students seeking TE enrolment (Marmolejo, 2016). These trends are bolstered by the growth of knowledge economies - generating further demand for graduates with advanced TE skills. According to recent estimates, by the year 2020 there could be a 40 million supply gap in tertiary educated employees in specialized areas such as green technology industries (UNESCO, 2016).

In the wake of this increased demand, governments especially in LDCs struggle with the challenge of how to fund TE. Two main models of financing have been established: the European state funded model and the increasingly preferred mixed private-public funding American model. Both models have their advantages and disadvantages. State funding facilitates broader access to education, but bears the burden of limited fiscal resources that often - especially in LDCs - compete with other more pressing social demands. The American model shares the costs of financing, but often overburdens the students: Tuition fees in the U.S. have nearly doubled in the last 20 years, resulting in student debt of nearly $\$ 1.2$ trillion (Economist, 2015).

Moreover, access to TE in these countries is strikingly inequitable: minority and socio-economically weak students are much less likely to go to university. Studies show that in Malawi, for example, only one percent of TE students are from the lowest income bracket, compared with over 80 percent from the highest (World Bank 2013a cited in World Bank, 2015). These findings are particularly applicable for LDCs, but also valid across industrialized countries. Dropout rates for underprivileged students struggling with significant student debts were also much higher. This data strongly suggests that even for countries that have a public funding system in place, it is essentially students from higher socioeconomic backgrounds who profit most from TE (Marmolejo, 2016). 




Figure 3. Gross enrolment ration in education, by country income group (World Bank Development Indicators (database) cited in Marmolejo 2016, 18)

For those fortunate students who do succeed in TE enrolment, research shows that they will be well rewarded for their efforts. Graduates can expect an earnings increase of around 17 percent -- a much higher return to investment than for primary and secondary education (World Bank Group, 2015). However, not all countries have the capacity and economic infrastructure to absorb their university graduates. Several countries, including China, India and, in particular, Sub-Saharan Africa, have high graduate unemployment rates. Part of the problem is that the quality of education is often inadequate and also that graduates are not learning the relevant market skills required for working in advanced globalized service economies (World Bank Group, 2017a; Marmolejo, 2016).

\section{Conclusion}

The purpose of this paper has been to bring TE into the discourse on sustainable development. To this end, I examined recent empirical studies and theoretical approaches relating to the field. I began by briefly summarizing the theoretical context underpinning economic explanations of the relationship between human capital and economic development. The conclusion from this brief overview was that although differing theoretical approaches exist, there was a consensus in the core findings: building on human capital is a prerequisite for sustainable development. Following this, I examined studies assessing the social and economic contributions of TE, which covered aspects ranging from the traditional TE functions of teaching and research to more recent considerations of TE's third mission benefits. The first two TE functions considered the economic impact of factors such as earnings, productivity and innovation. The third mission impacts were discussed in the context of firstly, private gains such as health improvements and fertility rates, and secondly, social benefits such as environmental and institutional reforms. Again, although there were some inconsistencies in empirical studies, the overwhelming evidence pointed to a positive association between TE and sustainable development.

My review of literature revealed several gaps in research with regard to the relationship between TE and sustainable development. One explanation for this paucity of research is that for the past two decades international funding and resources have been channelled into the SDG focus of promoting first and foremost basic education (Kruss et al., 2015). Although measuring the full economic impacts of TE has proven challenging, the general conclusion from studies in this field was that the impact of TE on sustainable development may be far more positive than previously assumed. Numerous studies confirmed individual gains from TE in the form of increased earnings. However, there were significantly fewer studies addressing the macro-level benefits resulting from higher productivity levels or increased innovative activity. Nonetheless, these studies similarly reported positive impacts, justifying an appeal for further research in this area. Notable was also a distinct lack of studies dealing with the non-market benefits of TE, especially in connection with third mission benefits to local communities and society in general. In particular, more research is required to assess the social outcomes of TE in areas such health, democracy, and environment. Finally, there were calls from several authors for research that examined the potential synergies and additional benefits resulting from the complementary interactions of all three TE functions (Oketch, McCowan and Schendel, 2014). 
Shifting focus from the potential benefits of HE, this paper also touched on the current challenges facing TE institutions. It seems pertinent at this point to highlight the most promising and innovative responses mentioned in the literature. The main challenges discussed were funding the increasing demand for TE, ensuring equal access to enrolment and providing market relevant curricula content. In answer to these challenges, new forms of TE institutions around the globe are being established. These include private and public technical and community colleges, cooperative universities, distance-learning centres, and virtual universities. Ideally, the increased competition from the expanded supply of TE providers will lead to more accessible, affordable, flexible and market-relevant forms of advanced study. However, the success of these institutions will ultimately depend on the effectiveness of the quality assurance systems in place (Marmolejo, 2016). The advantages of online-learning have yet to be fully explored and implemented: with just 11 percent market share, the U.S. currently leads global enrolment in fully online courses. The potential advantages include savings on the high costs of brick and mortar buildings, access to high quality instructors worldwide, and engaging multi-media materials delivered with state of the art online learning technologies (Šlaus and Jacobs, 2011). This could be a promising area for future TE investment from governments and the international development community.

Although I have attempted to cover the most important issues and literature pertaining to the impacts of TE, a complete coverage of all aspects would go beyond the scope of this paper. An interesting area to explore further would be additional challenges to TE as well as potential approaches and solutions. However, the focus here has been on the impact of TE on sustainable development.

The pressing global issues stressed in my opening remarks make the SDGs as relevant as when they were first established. Moreover, my findings confirm that TE plays a central role in positively contributing to these goals. Given the current lags in research and the mounting demands for TE institutions especially in LDCs, this paper argues that the time has come for the international community to devote more attention to TE in its pursuit of sustainable development.

\section{References}

Aghion, P., \& Howitt, P. (1992). A model of growth through creative destruction. Econometrica, 60(2), A323-351. Retrieved from https://www.jstor.org/stable/2951599

Arrow, K. J. (1962). The economic implications of learning by doing. The Review of Economic Studies, 29(3), 155-173. Retrieved from https://www.jstor.org/stable/2295952

Barro, R. J., \& Sala-i-Martin, X. (2003). Economic growth. Cambridge, Mass.: MIT.

Bloom, D. E., Canning, D., Chan, K., \& Luca, D. L. (2014). Higher education and economic growth in Africa. International Journal of African Higher Education, 1(1), 23-57. Retrieved from https://ejournals.bc.edu/ojs/ index.php/ijahe/article/view/5643/4974

Economist. (2015). The world is going to university. More and more money is being spent on higher education. Too little is known about whether it is worth it. Economist (Special issue), 2-6. Retrieved from https:// www.economist.com/printedition/2015-03-28

Franzen. A., \& Vogl, D. (2013). Two decades of measuring environmental attitudes: A comparative analysis of 33 countries. Global Environmental Change, 23(5), 1001-1008. https://doi.org/10.1016/j.gloenvcha.2013.03.009

Gillies, D. (2014). Human capital, education, and sustainability. Sisyphus Journal of Education, 2(3), 78-99.

Hanushek, E. A. (2016). Will more higher education improve economic growth? Oxford Review of Economic Policy, 32(4), 538-552. https://doi.org/10.1093/oxrep/grw025

Hanushek, E. A., \& Woessmann, L. (2015). The knowledge capital of nations: Education and the economics of growth. Cambridge, MA: Massachusetts Institute of Technology. Retrieved from https://www.amazon.com/Knowledge-Capital-Nations-Education-Economics/dp/0262029170

ISSP Research Group. (2012). International social survey programme: Environment III - ISSP 2010. GESIS Data Archive, Cologne. ZA5500 Data file Version 2.0.0. Retrieved from https://dbk.gesis.org/dbksearch/sdesc2.asp?no=5500

Kruss, G., McGrath, S., Petersen, I., \& Gastrow, M. (2015). Higher education and economic development: The Importance of building technological capabilities. International Journal of Educational Development, 43, 22-31. https://doi.org/10.1016/j.ijedudev.2015.04.011 
Lucas, R.E. (1988). On the mechanics of economic development. Journal of Monetary Economics, 22(1), 3-42. https://doi.org/10.1016/0304-3932(88)90168-7

Mankiw, N., Romer, D., \& Weil D. (1992). A contribution to the empirics of economic growth. Quarterly Journal of Economics, 107(2), 407-37. https://doi.org/10.2307/2118477

Marmolejo, F. (2016). What matters most for tertiary education systems: A framework paper: Systems approach for better education results. SABER Working Paper Series. Retrieved from http://wbgfiles.worldbank.org/ documents/hdn/ed/saber/supporting_doc/Background/TED/SABER_Tertiary_\%20Framework.pdf

Mincer, J. (1974). Schooling, experience, and earnings. New York, NY: NBER.

Montenegro, C. E., \& Patrinos, H. A. (2014). Comparable Estimates of Returns to Schooling around the World. Policy Research Working Paper 7020. Washington, DC: World Bank Group. Retrieved from https://elibrary.worldbank.org/action/showPublications?SeriesKey=prwp\&

Neyerere, J., Mfune, O., Fuh, D., Sulemana, N., Mutisya, E., Yiran, G., Fadairo, O., Ameyaw, J., \& Odingo, A. (2016). The role of higher education in building a sustainable African society. African Journal of Sustainable Development, 4(3), 17-37.

Nelson, R. R., \& Phelps, E. (1966). Investment in humans, technology diffusion and economic growth. American Economic Review, 56(2), 69-75.

Oketch, M., McCowan, T., \& Schendel, R. (2014). The impact of tertiary education on development: A rigorous literature review. London, UK: University of London.

OECD. (2015). Organisation for Economic Co-operation and Development. Universal basic skills: What countries stand to gain. OECD Publishing. Retrieved from http://www.oecd.org/edu/universal-basic-skills-9789264234833-en.htm

OECD. (2017). Organization for Economic Co-operation and Development. Green growth indicators 2017. OECD Publishing, Paris, FR. from http://www.oecd.org/env/green-growth-indicators-2017-9789264268586-en.htm

Romer, P. M. (1990). Endogenous technological change. Journal of Political Economy, 9(5), 71-102. https://doi.org/10.1086/261725

Salmi, J., \& Bassett, R. M. (2014). The equity imperative in tertiary education: Promoting fairness and efficiency. International Review of Education, 60(3), 361-377. https://doi.org/10.1007/s11159-013-9391-z

Slaus, I., \& Jacobs, G. (2011). Human capital and sustainability. Sustainability, 3, 97-154. https://doi.org/10.3390/su3010097

Solow, R. M. (1956). A contribution to the theory of economic growth. Quarterly Journal of Economics, 70(1), 65-94. https://doi.org/10.2307/1884513

UN. (2014). United Nations. The Millennium Development Goals Report 2014. New York, NY: United Nations.

UN. (2015). United Nations. Transforming our world: The 2030 agenda for sustainable development. Retrieved from

https://sustainabledevelopment.un.org/content/documents/ 21252030\%20Agenda\%20for\%20Sustainable\%20Development\%20web.pdf

UN. (2018). United Nations. Global Issues Overview. Retrieved from http://www.un.org/en/sections/issues-depth/global-issues-overview/

UNESCO. (2011). United Nations Educational, Scientific and Cultural Organization. International Standard Classification of Education ISCED 2011. Paris, FR: UNESCO. Retrieved from $\mathrm{http}$ //www.uis.unesco.org/Education/Pages/international-standardclassification-of-education.aspx

UNESCO. (2016). United Nations Educational, Scientific and Cultural Organization. Global education monitoring report. Planet: Education for environmental sustainability and green growth. Paris, FR: UNESCO. Retrieved from http://unesdoc.unesco.org/images/0024/002464/246429E.pdf

Van den Berg, H. (2017). Economic growth and development. London, UK: World Scientific Publishing. Retrieved from https://www.amazon.de/Economic-Growth-Development-Hendrik-Berg-ebook/dp/B01LZD0TGC/ref=sr_1 $\_1$ ? $\mathrm{ie}=\mathrm{UTF} 8 \& q \mathrm{id}=1520017011 \& \mathrm{sr}=8-1 \&$ keywords $=$ Economic + Growth + and + Development $\% 3 \mathrm{~A}+$ berg\#trea der_B01LZD0TGC 
World Bank Group. (2015). Driving development with tertiary education reforms: Education global practice. Smarter education systems for brighter futures. Retrieved from http://documents.worldbank.org/curated/en/ 613701468188661472/pdf/98454-REVISED-Box393212B-PUBLIC.pdf

World Bank Group. (2017a). Higher Education for Development. An Evaluation of the World Bank group's Support. Retrieved from http://documents.worldbank.org/curated/en/729101493052924041/pdf/ 113867-WP-REVISED-PUBLIC.pdf

World Bank Group. (2017b). Tertiary education overview: Higher Education, 5 October. Retrieved from http:// www.worldbank.org/en/topic/tertiaryeducation

World Bank Group. (2018). Sustainable development: Understanding poverty. Retrieved from http://www.worldbank.org/en/topic/sustainabledevelopment/overview

World Commission on Environment and Development. (1987). Our common future: Report of the world commission on environment and development. In G. H. Brundtland. (Eds.). Oxford, UK: Oxford University Press. Retrieved from http://www.un-documents.net/our-common-future.pdf

\section{Copyrights}

Copyright for this article is retained by the author(s), with first publication rights granted to the journal.

This is an open-access article distributed under the terms and conditions of the Creative Commons Attribution license (http://creativecommons.org/licenses/by/4.0/). 